\title{
PRODUCTION AND EVALUATION OF FORTIFIED SNACK FOOD EXTRUDATE WITH FISH FLOUR
}

Atwa, Manal A. ${ }^{1}$; M. A. Atwa ${ }^{1}$; Kh. M. Elmeleigy' ${ }^{1}$; I. A. El-Saies ${ }^{2}$ and Kh. M. Abd El-Latif ${ }^{3}$

1- Regional Center for Food and Feed, Agric. Research Center, Ministry of Agricultural, Giza, Egypt.

2- Food Tech. Dept. Faculty of Agric., Suez Canal Univ., Ismailia, Egypt.

3- Specialized Hospital ,Ain Shams University.

\begin{abstract}
A formula containing rice flour, powdered Nile Perch fish flour, turmeric and fine salt was extruded. Extrusion processing was used to produce a new value-added food with enhanced nutritional and sensory properties using single-screw extruder. Microbiological and nutritional quality assessment was performed for the snack food product. Whereas protein, essential amino acids are important for growth and the micro elements for the Iron and Zinc deficiency which are highly prevalent among young children in Egypt. Fish is excellent source of lipid that contains $n-3$ faty acids. Accurate ratios of Nile perch fish flour by 10 and $12.5 \%$ were used in formulae. The study of functional properties of the product had proved that the extruded product gained good characteristics (proper density, expansion ratio, breaking strength, taste and color) and was acceptable to feed by consumer. Obtained results proved that both fish flour ratios were proper; only use the proportion of $10 \%$ of the fish was better in terms of smell and taste as well as a chemical assessment was appropriate and results showed high proportion of protein to $20.6 \%$. The total amino acids were 16.68 $\mathrm{g} / 100 \mathrm{~g}$ sample. The microbiological evaluations proved the validity of such products and free of pathogenic microbes such as Salmonella, Bacillus cereus, and Staphylococcus aureus. Macro elements such as calcium gave $1.93 \mathrm{~g} / 100 \mathrm{~g}$ sample while it was $0.89 \mathrm{~g} / 100 \mathrm{~g}$ sample for phosphorus and $22.5 \mathrm{ppm}$ for iron; heavy metals did not exceed the allowable limits by Egyptian Standards Specifications2005.

Finally results indicated that it is possible to produce a highly acceptable snack of high nutritional quality that could be useful in feeding programs to counteract anemia and malnutrition in under developed countries.
\end{abstract}

Keywords: Extrusion Cooking; Fish snack; Physical properties, Rice flour, Amino acids, Heavy metals.

\section{INTRODUCTION}

In the recent years extrusion cooking has become one of the most popular newcomer developed process. Cereals have excellent expansion properties and are well suited for thermal extrusion.

Many applications of extrusion cooking include the production of breakfast cereals, snacks, beverage powders, infant foods, pasta products and blended foods. The major applications include the production of breakfast cereals and snacks.

In Egypt, at the present time, snacks become more consumed especially children at different ages. Many kinds of snacks have been 


\section{Atwa, Manal A. et al.}

produced; however, most of those snacks are made of starch and sugar, therefore, their nutritive values are rather low.

Most of which are poor sources of protein and its protein is often of poor nutritional quality. Thus protein supplementation is needed to increase the protein efficiency ratio and increase the total amount of protein (Matz, 1976).

Fish can be added to increase the protein content of snacks, e.g., in fish strip that is one of the popular snacks in Thailand with a market share of about 10 (Boonyasirikul, 1998).

Fish are not only excellent sources of high nutritional value of protein but also excellent sources of lipid that contains n-3 fatty acids, especially, eicosapentaenoic (EPA) and docosahexaenoic (DHA) acids (Kris-Etherton et al., 2000. The n-3 fatty acids are essential for normal growth and development and may prevent or moderate coronary artery disease, hypertension, diabetes, arthritis, others inflammatory and autoimmune disorders, as well as cancer (Simpopoulos, 2000)

These potential effects have gained the interest of food processors, the medical community and consumers had increased promote numbers of products containing n-3 fatty acids (Augustin and Sanguansri, 2003).

Dried fish, after separation of bones, has been utilized from these sources for production of various value-added fishery products (Grantham,1981). But the minced fish lacks good textural properties, which can be improved by processing through food extruders (Choudhury and Gogoi,1995). When dried fish is blended with rice flour, and co-extruded, some promising snack food products with nutritional combinations are produced. Rice is also a good source of vitamins and minerals, but low in fat and sodium (Dziezak, 1991). Some studies on single screw extrusion of fish blended with rice, wheat and other starchy ingredients for product and process development have been reported by Murray and Stanley 1989; Yu et al., 1981; Bhattacharya et al., 1986; Clayton and Miscourides 1992.

The present work has been carried out to utilization the dried fish flour in preparing snack food by using single screw extruder. The characteristics of the resultant extrudate: functional, chemical, microbiological and sensory properties of the end product were studied.

\section{MATERIALS AND METHODS}

- Ten varieties of fish included Red mullet, Mullet, Sardines, Nile perch, Tilapia, Synodontida, Salmon, Mackerel, Tuna and Grass carp were purchased from Egyptian local market.

- The fresh water fish, Nile perch (Lates niloticus) was selected due to its low bones and fat contents for the preparation of extruded snack food.

Fresh fish was prepared by removing the head, fins, tail and viscera then washed with water. The prepared fish was dried at $60-65^{\circ} \mathrm{C} / 3 \mathrm{~h}$ in tray dryer to about $10 \%$ moisture content and the dried fish was grind in a super blender (Moulinex $300 \mathrm{w}$ - type 721). Fish powder was sieved, and passed through $500 \mu \mathrm{m}$ sieve. 
- Rice flour was purchased from the local market and groaned in super

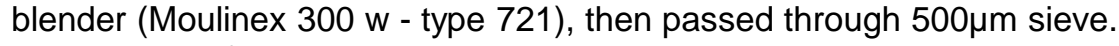

- Fish and rice flours were packed in sealed polyethylene bags and stored in a refrigerator before using.

\section{Preparation of blends:}

Nile perch fish flour was substituted with rice flour at $10.0 \%$ and $12.5 \%$ represented as formula 1 and 2 as shown in table (1).

Table (1): Substitution of rice grits with two types of Nile Perch fish flours.

\begin{tabular}{|l|c|c|}
\hline \multicolumn{1}{|c|}{ Ingredients } & $\begin{array}{c}\text { Formula 1 } \\
\text { (\%) }\end{array}$ & $\begin{array}{c}\text { Formula 2 } \\
\text { (\%) }\end{array}$ \\
\hline Rice grits & 87.8 & 85.3 \\
\hline Fish flour & 10.0 & 12.5 \\
\hline Fine Salt & 2.0 & 2.0 \\
\hline Turmeric & 0.2 & 0.2 \\
\hline
\end{tabular}

The ingredients were thoroughly mixed by using a mechanical mixer in $1-\mathrm{kg}$ batches. Water was added (in spray form) to adjust the moisture content of blends to $16 \%$ and mixed well again. Blends were packed in polyethylene bags and stored at refrigeration condition for $24 \mathrm{hr}$ before extrusion to allow the moisture to equilibrate.

\section{Extrusion:}

A Brabender laboratory single-screw extruder (20 DN), Model No. 186501 type 832500 equipped with feeding device AEV 300, No. 141923, type GNF 1014/2; Do-Coder (EDCE 330) to control the feeding device speed, temperature regulators for two extruder zones and die head; compressed-air cooled collars controlled by thermostat; a uniformity tapered screw shaft with a 4:1screw comparison ratio was used, whereas a die rod type $3 \mathrm{~mm}$ was chosen. This model of extruder had a $20 \mathrm{~mm}$ diameter spiral grooved barrel with a length to diameter ratio (L/D) of 20:1.

Many experiments were done on the extruder to define the best conditions appropriated to produce high protein products. These conditions were: the screw speed was set at $250 \mathrm{rpm}$; the raw mixes were fed at a rate of $160 \mathrm{rpm}$ and the feeding, cooking and die zones temperatures were adjusted at 100,140 and $160{ }^{\circ} \mathrm{C}$, respectively. When all zones of the extruder reached to the desired temperature, the ingredients were discharged into extruder hopper. The feed screw speed was increased slowly up to desired set feed rate. When the extruder reached to the steady state, dough temperatures were read directly from the digital indicators for each trial. The resultant extrudates were directly dried in an air oven drier at $110^{\circ} \mathrm{C}$ for 15 $\mathrm{min}$ and allowed to reach room temperature. Immediately after processing, the samples of extrudates were collected in polyethylene bags, sealed and stored at room temperature $\left(30 \pm 5^{\circ} \mathrm{C}\right)$ until analyses.

Commercial snack fish food samples:

Fifty snack food samples containing fish powder were purchased from local markets in Egypt. Samples were divided into five groups. Every group 
included ten samples which had the same contents and same manufacturer. Representative samples from the groups $1,2,3,4,5$ and the fortified snack food product under investigation were analyzed to study its chemicals and microbiological state. The results were compared .

\section{Functional properties:}

Expansion ratio of extrudates was calculated by dividing the average cross-sectional area of the extrudates by the average cross-sectional area of the die-nozzle orifice, according to Chinnaswamy and Hanna (1988). Each value was the average of 10 readings. Breaking strength was determined according to the method described by Abd el hady et al,2002 using Brabender Struct-O-Graph Model No. 8603 OHG Dusiburg. The samples were resited on two parallel support bars that attached to an elevator plate form that is raised at constant speed to contact a sensor bar mounted above the sample and equidistant between and parallel to the lower knife edges. A strip char record gives a force-time plot. The equipment was fitted with a 500$\mathrm{cmg}$ spring and a plexi glass beam. The beam travel speed was $9 \mathrm{~mm} /$ minute. The peak height of the resultant recorded curves (as Brabender units) for each sample was taken as a texture measure (Breaking Force Index). To test extruded rope samples, 10 measurements were taken for each sample. The water absorption index (WAI) and the water solubility index (WSI) were determined according to Andersson et al. (1969).

Bulk density (BD) of extruded samples was determined by Okezie and Bello (1988).

\section{Chemical analysis:}

Moisture, protein, ash, crude fiber and, total lipid contents were determined according to the methods described by the A.O.A.C. (2008), total carbohydrate was calculated by differences.

Amino acids of samples were determined according to Benson and Patterson (1965) by using high performance amino acid analyzer (U.S.A) Beckman System 7300 and Data System 7000, supplemented with column type $\mathrm{Na} / \mathrm{A} / \mathrm{B} / \mathrm{D} 25 \mathrm{~cm}$. the volume of injected sample was $50 \mu \mathrm{l}$.

\section{Minerals analysis :-}

Minerals were determined according to the methods described by the( A.O.A.C,2008). All samples and standards has been analysed by ICP- peker elmer , optical Emission Spectrometer , Optima 2000DV.

\section{Microbiological Evaluation:}

Appropriate dilutions prepared from each sample were used for inoculating different nutrient and selective media. The microbial determinations were applied as follows:

\section{Total plate counts:}

Aerobic bacterial counts were estimated on glucose yeast extract nutrient agar medium as the method described by (ISO, 2002) using pouring plate technique. Suitable plates were counted after incubation at $37^{\circ} \mathrm{C}$ for 48 hours.

Total Coliform and faecal coliform counts:

Coliform and faecal coliform counts were estimated on MacConkey agar (ISO, 2002 ) using pouring plate technique. Suitable plates were 
counted after 24 hours at $37^{\circ} \mathrm{C}$ and $44.5^{\circ} \mathrm{C}$ for total coliform and faecal coliform counts, respectively.

Detection of Salmonella:

Salmonella was detected according to the method described by (USDA,2002). Fivty gram of homogenized sample was inoculated into 225 $\mathrm{mL}$ of Buffered Peptone Water (BPW), and incubated for $24 \mathrm{~h}$ at $37^{\circ} \mathrm{C}$ then five $\mathrm{ml}$ of previous step was added to 225 of tetrathionate broth and incubated for $20-24 \mathrm{~h}$ at $35^{\circ} \mathrm{C}$ to streaked on bismuth sulfite agar and incubated for another $24 \mathrm{~h}$ at $37^{\circ} \mathrm{C}$. Presumptive Salmonella appears as brown colonies surrounded by bright red medium).

Bacillus Cereus:

Twenty five g. of samples were enriched in $225 \mathrm{ml}$ of Trypticase soypolymixin broth for 18 to $24 \mathrm{~h}$ at $30^{\circ} \mathrm{C}$ and then plated on mannitol-egg yolk-polymixin agar and incubated for 18 to $24 \mathrm{~h}$ at $30^{\circ} \mathrm{C}$ (Smithet al .,2004).

Staphylococcus aureus :

Staphylococcus aureus was detected according to the method described by (Gouda 2002). The isolation of staph . aureus based on appears as black, convex, shiny colonies surrounded by a yellow zone on vojel Johnson agar medium.

\section{Total Fungal Count:}

Total counts of fungi were determined on potato dextrose agar (Oxoid manual , 2000). Plates were incubated at $22-25^{\circ} \mathrm{C}$ for 7 days. All results were averaged of two replicate .

\section{Sensory evaluation:}

The sensory evaluation of the extrudate samples was carried out Sensory properties were included; taste (20), crispness (20), odor (20), chewiness (10) color (10), surface characteristics (10) and pore distribution (10) were judged by ten staff members of Food Technology Department. The overall acceptability of the samples was calculated from the total score of rested attributes (out of 100). The grades were given according to the following scale; excellent (86-100), good (76-85), fair (61-75) and poor (5160 ) as described by Abu-Foul (1990).

\section{Statistical analysis}

Data were presented as mean and standard deviation values. Analysis of variance (ANOVA) was used to compare between means of amino acids values $(\mathrm{g} / 100 \mathrm{~g}$ dry samples) and some fish varieties. Duncan's post-hoc test was used to determine significant differences between the means. The significant level was set at $p<0.05$. Statistical analysis was performed with SPSS 15.0 (statistical package for scientific studies) for windows The least significant difference (ISd) was calculated at the probe-ability level $\mathrm{P}<0.05$. (Geofferey and Streines , 2003).

\section{RESULTS AND DISCUSSION}

Rice flour and Nile perch fish (Lates niloticus) were chosen to be extruded in this study. The Nile Perch fish is a species of fresh water fish in 
family latidae. It is wide spread throughout much of the A frotropic ecozone being native to Egypt (pringle, 2005). It is occurs in water of Maryut lake in Egypt. It is great commercial important as a food fish.

Chemical composition of different variety of fish flour :

Results in Tables 2, 3 and 4 show the percentage of the crude protein , amino acids levels, and minerals of the ten varieties of fish flour .

It could be shown from the results in table (2) that the protein content ranged from 52.60 to $94 \%$. The highest protein content was with dried grass carp fish flour, while salmon and mackerel fish flour had the lowest protein content (52.60 and $58.10 \%$ respectively). Meanwhile the protein content of Nile perch fish flour was $82.70 \%$.

Amino acids composition of fish flour varieties is showed in Table (3). Data indicated that all investigated samples were very good sources or essential amino acids. Result indicated that Nile perch contained the highest amount of total amino acids being $84.2 \%$.

Table (2): Crude protein contents of ten fish flour varieties.

\begin{tabular}{|l|c|}
\hline \multicolumn{1}{|c|}{ Fish type } & $\begin{array}{c}\text { Crude protein content } \\
\text { (g/100g dry sample })\end{array}$ \\
\hline Red mullet & 74.30 \\
\hline Mullet & 74.80 \\
\hline Sardines & 71.80 \\
\hline Nile perch & 82.70 \\
\hline Tilapia & 89.60 \\
\hline Synodontida & 82.30 \\
\hline Salmon & 52.60 \\
\hline Mackerel & 58.10 \\
\hline Tuna & 83.00 \\
\hline Grass carp & 94.00 \\
\hline
\end{tabular}

The acidic amino acids (Aspartic and Glutamic acids constituted about $28.38 \%$ of the total amino acid of Nile perch flour sample. The corresponding values for aspartic and glutamic acids had 10.73 and $13.17 \mathrm{~g} / 100 \mathrm{~g}$ dry matter of sample.

The basic amino acids (Lys., His., and Arg.) constituted about $18.09 \%$ of the total amino acids of Nile perch fish flour, the values of Lys., His., and Arg., were $9.13,2.41$ and $3.70 \mathrm{~g} / 100 \mathrm{~g}$ dry matter of sample.

Regarding the natural amino acids (Thr., Ser., Pro., Gly., Ala., Val., Leu. and Iso.) of Nile perch fish, it is clear that it was ranged from 3.12 to 8.30 $\mathrm{g} / 100 \mathrm{~g}$ dry matter of sample.

Results in Table (4) show the contents of mineral of the tested samples. Data indicated that, fish flour samples are considered rich sources of minerals especially calcium, potassium and phosphorus.

The highest amount of potassium could be shown for the varieties tuna and Nile perch, they had 11730 and 10870 ppm, respectively. The calcium content of Nile perch was only $204.1 \mathrm{ppm}$, meanwhile it was in high amount for synodontida variety that amount as $7766 \mathrm{ppm}$. However ,the Nile perch fish variety had only $230 \mathrm{ppm}$ of phosphorus, that was not good as Tuna that contained 12210ppm of phosphorus. 
J.Agric.Chem.and Biotechn., Mansoura Univ.Vol. 4 (4), April, 2013 3 
Atwa, Manal A. et al.

Table (4): Some elemental contents of ten fish flour varieties(ppM).

\begin{tabular}{|l|c|c|c|c|c|c|c|c|c|c|}
\hline $\begin{array}{c}\text { minera } \\
\text { type } \\
\text { (PPM) }\end{array}$ & $\begin{array}{c}\text { Red } \\
\text { mullet }\end{array}$ & Mullet & Sardines & $\begin{array}{c}\text { Nile } \\
\text { perch }\end{array}$ & Tilapia & Synodontida & Salmon & Mackerel & Tuna & $\begin{array}{c}\text { Grass } \\
\text { carp }\end{array}$ \\
\hline $\mathrm{Ca}$ & 4324 & 349.4 & 2988 & 204.1 & 7707 & 7766 & 1022 & 104.5 & 7355 & 299.3 \\
\hline $\mathrm{P}$ & 8181 & 7309 & 8660 & 7230 & 9853 & 9900 & 7472 & 8325 & 12210 & 5474 \\
\hline $\mathrm{Cu}$ & $*$ U.D.L & U.D.L & U.D.L & U.D.L & U.D.L & U.D.L & U.D.L & U.D.L & U.D.L & U.D.L \\
\hline $\mathrm{Fe}$ & 55.26 & 52.09 & 100.1 & 73.71 & 28.53 & 28.53 & 69.0 & 122.5 & 38 & 110.1 \\
\hline $\mathrm{k}$ & 7643 & 10620 & 9372 & 10870 & 10700 & 10600 & 8623 & 9703 & 11730 & 6968 \\
\hline $\mathrm{Mg}$ & 430.0 & 265.6 & 299.0 & 469.4 & 520.9 & 487.9 & U.D.L & 607.7 & 838.3 & U.D.L \\
\hline $\mathrm{Mn}$ & U.D.L & U.D.L & U.D.L & U.D.L & U.D.L & U.D.L & U.D.L & U.D.L & U.D.L & 4.171 \\
\hline $\mathrm{Na}$ & 1757 & U.D.L & 1503 & U.D.L & 1024 & 990.8 & U.D.L & 4219 & 312.5 & U.D.L \\
\hline $\mathrm{Zn}$ & 6.896 & 6.739 & 33.89 & 19.18 & 16.98 & 16.04 & 3.01 & 12.80 & 8.04 & 8.498 \\
\hline
\end{tabular}

* U.D.L = under detection limit.

\section{Chemical composition of different fish fortified snacks:}

Results in Table (5) show average of the chemical composition of the tow prepared formula from fish flour (final product) and those samples purchased from the local market.

Table (5): The chemical composition of the final product

\begin{tabular}{|l|c|c|c|c|c|c|}
\hline \multicolumn{1}{|c|}{ Property } & Final product & $\mathbf{1}$ & $\mathbf{2}$ & $\mathbf{3}$ & $\mathbf{4}$ & $\mathbf{5}$ \\
\hline Moisture\% & $6.0 \%$ & 3.5 & 3.2 & 2.2 & 4.6 & 5.1 \\
\hline Protein \% & $20.6 \%$ & 5.19 & 8.05 & 8.4 & 8 & 5.6 \\
\hline Ash \% & $1.95 \%$ & 1.2 & 1.1 & 1 & 1.2 & 1.3 \\
\hline Crud fiber \% & $0.36 \%$ & 3.2 & 2.3 & 2 & 1.2 & 2 \\
\hline Ether extract \% & $0.76 \%$ & 41 & 29.2 & 29.5 & 21 & 11.8 \\
\hline Total carbohydrates \% & $70.33 \%$ & 45.9 & 56.15 & 56.9 & 64 & 74.2 \\
\hline
\end{tabular}

( ${ }^{\star}$ Total carbohydrates were calculated by difference.)

Results showed that protein content of the product was $20.6 \%$; while the ether extract was $0.76 \%$ and the total carbohydrate was $70.33 \%$. Obtained data were in agreement with the results obtained by Rhee et al. (2004) who studied the proximate compositions of different cat fish with corn and defatted soy flour extruded product and reported that fat content was very low, while moisture, protein and ash values were $2.2-2.9 \%, 11.4-11.7 \%$ and $1.1-1.2 \%$, respectively.

Table (6) show the mineral content as well as the heavy metals for the different fortified fish snack either prepared with the Nile perch or those purchased from the local market .

It was observed that, the macro elements such as calcium gave value $1.93 \%$ and covered $100 \%$ from the recommended daily allowances (RDA) (500 mg / day for young) according to (NAS) National Academy of science (2001), while $0.89 \%$ for phosphorus and $22.5 \mathrm{ppm}$ for iron which represent a ratio of $25 \%$ of RDA (10 mg / day). Also, it noticed that the heavy metals don't exceed of the allowed limits by Egyptian Standard Specification (2005). 
Table (6): Macro, Micro elements and heavy metals of the final product

\begin{tabular}{|c|c|c|c|c|c|c|}
\hline \multirow{2}{*}{$\begin{array}{c}\text { Macro } \\
\text { elements }\end{array}$} & \multirow{2}{*}{$\begin{array}{c}\% \\
\text { Final product } \\
\end{array}$} & \multicolumn{5}{|c|}{40} \\
\hline & & 1 & 2 & 3 & 4 & 5 \\
\hline $\mathrm{Na}$ & 6.3 & 7.48 & 8 & 8 & 7.7 & 8.2 \\
\hline $\mathrm{Ca}$ & 1.93 & 1.4 & 1.6 & 1.2 & 0.8 & 1.1 \\
\hline $\mathrm{P}$ & 0.89 & 0.15 & 0.18 & 0.19 & 0.16 & 0.21 \\
\hline $\mathrm{K}$ & 1.113 & 1.9 & 2.05 & 2.2 & 0.2 & 0.3 \\
\hline $\mathrm{Mg}$ & 0.983 & 1.1 & 0.86 & 1.4 & 1.3 & 1.6 \\
\hline Micro elements & PPM & & & & & \\
\hline $\mathrm{Fe}$ & 22.5 & 19.5 & 81 & 47 & 29.4 & 33 \\
\hline $\mathrm{Cu}$ & 0.11 & UD & UD & UD & UD & UD \\
\hline $\mathrm{Mn}$ & 18.36 & 4.85 & 9.73 & 5.78 & 4.31 & 4.6 \\
\hline $\mathrm{Zn}$ & 21.66 & 7.6 & 1.02 & 14.1 & 5.9 & 4.1 \\
\hline Heavy metals & ppM & & & & & \\
\hline $\mathrm{Pb}$ & 0.18 & 2.59 & 2.96 & 3.93 & 2.94 & 2.8 \\
\hline $\mathrm{Ca}$ & 0.09 & 0.94 & 0.93 & 0.96 & 1.02 & 0.91 \\
\hline $\mathrm{Ni}$ & 0.43 & 0.81 & 0.66 & 0.71 & 0.74 & 0.81 \\
\hline As & 0.18 & 0.31 & 0.81 & 0.71 & 0.75 & 0.25 \\
\hline $\mathrm{Al}$ & 23.1 & 41.6 & 25.5 & 35.9 & 44.2 & 41.0 \\
\hline $\mathrm{Ag}$ & 0.055 & 0.09 & 0.08 & 0.09 & 0.91 & 0.81 \\
\hline Co & 0.19 & 0.21 & 0.31 & 0.16 & 0.41 & 0.3 \\
\hline $\mathrm{Cr}$ & 2.86 & 4.19 & 4.17 & 4.64 & 4.37 & 4.2 \\
\hline
\end{tabular}

Table (7):The Amino Acids content of final product ( $\mathrm{g} / 100 \mathrm{~g}$ sample)

\begin{tabular}{|l|c|c|c|c|c|c|}
\hline $\begin{array}{c}\text { Amino acids g/100g } \\
\text { sample }\end{array}$ & Final product & $\mathbf{1}$ & $\mathbf{2}$ & $\mathbf{3}$ & $\mathbf{4}$ & $\mathbf{5}$ \\
\hline Aspartic & 1.79 & 0.55 & 0.85 & 0.91 & 0.89 & 0.56 \\
\hline Therionine & 0.78 & 0.25 & 0.37 & 0.42 & 0.36 & 0.30 \\
\hline Serine & 0.8 & 0.26 & 0.38 & 0.41 & 0.35 & 0.25 \\
\hline Glutamic & 3.04 & 0.97 & 1.44 & 1.51 & 1.41 & 0.85 \\
\hline Proline & 0.74 & 0.25 & 0.35 & 0.41 & 0.33 & 0.41 \\
\hline Alanine & 0.94 & 0.29 & 0.44 & 0.51 & 0.41 & 0.31 \\
\hline Glysine & 0.81 & 0.24 & 0.38 & 0.41 & 0.35 & 0.29 \\
\hline Valine & 0.84 & 0.25 & 0.40 & 0.45 & 0.42 & 0.32 \\
\hline Tyrosine & 0.86 & 0.27 & 0.41 & 0.45 & 0.38 & 0.31 \\
\hline Isoleucine & 0.72 & 0.22 & 0.38 & 0.41 & 0.41 & 0.30 \\
\hline Leucine & 1.46 & 0.45 & 0.69 & 0.71 & 0.66 & 0.50 \\
\hline Phenylalanine & 0.89 & 0.27 & 0.42 & 0.51 & 0.40 & 0.31 \\
\hline Histidine & 0.4 & 0.13 & 0.19 & 0.24 & 0.20 & 0.16 \\
\hline Lysine & 1.35 & 0.44 & 0.64 & 0.71 & 0.61 & 0.45 \\
\hline Argnine & 1.26 & 0.40 & 0.60 & 0.65 & 0.61 & 0.42 \\
\hline Total amino acids & 16.68 & 5.24 & 7.94 & 8.71 & 7.79 & 5.74 \\
\hline
\end{tabular}

Results in Table (7) show average of the Amino Acids composition of the tow prepared formula from fish flour (final product) and those samples purchased from the local market.

Results indicated that total amino acids of final product was 16.68 . Histidine was at a critical value $(0.4 \%)$, while glutamic acid was the highest value $(3.04 \%)$. 
Atwa, Manal A. et al.

Table (8): Microbiological evaluation of the final product

\begin{tabular}{|l|c|c|c|c|c|c|}
\hline \multicolumn{1}{|c|}{ Test } & Final product & $\mathbf{1}$ & $\mathbf{2}$ & $\mathbf{3}$ & $\mathbf{4}$ & $\mathbf{5}$ \\
\hline Total bacteria count (cfu/g) & $5 \times 10$ & $6 \times 10$ & 0.0 & 0.0 & 0.0 & 0.0 \\
\hline Total coliform count (cfu/g) & $3 \times 10$ & $5 \times 10$ & 0.0 & 0.0 & 0.0 & 0.0 \\
\hline Faecal coliform count (cfu/g) & 0.0 & $3 \times 10$ & 0.0 & 0.0 & 0.0 & 0.0 \\
\hline Staphylococcus aureus & $-\mathrm{ve}$ & - & - & - & - & + \\
\hline Bacillus cereus & $-\mathrm{ve}$ & - & - & - & - & - \\
\hline Salmonella( SPP). & $-\mathrm{ve}$ & - & - & - & - & - \\
\hline Total fungal count (cfu/g) & $-\mathrm{ve}$ & - & - & - & - & - \\
\hline E.Coli & - & - & - & - & - & - \\
\hline
\end{tabular}

Data in Table (8) showed microbiological evaluation which proved that; the final product was free from pathogenic bacteria.

\section{Functional properties of extrudates:}

\section{1- Expansion ratio (ER):}

The data presented in Table (9) showed that, substituting of rice grits with Nile perch fish flour resulted in reduction of expansion ratio.

Several researches demonstrated that, the expansion of extruded cereals was depending on the presence of the starchy component, which was altered by additives. Protein is one of these components, which retard ER of extrudates because it couldn't puff at high temperature. Same results were obtained by Faubion et al. (1982); Skierkowski et al. (1990); Gujska and Khan (1990); Abd El-Hady and Habiba (1996) and Abd El-Hady et al. (1997).

Table (9): Effect of addition of Nile perch fish flour on the functional properties of rice Extrudate.

\begin{tabular}{|l|c|c|c|c|c|}
\hline $\begin{array}{c}\text { Fish Flour substitution } \\
(\%)\end{array}$ & ER & BD (g/m) & WAl (g/g) & WSI (\%) & BS B.u \\
\hline 10 & 7.8 & 10.4 & 4.5 & 0.43 & 620 \\
\hline 12.5 & 7.5 & 10.5 & 4.4 & 0.45 & 630 \\
\hline
\end{tabular}

\section{2- Bulk Density (B.D):}

Bulk density of extrudates was an important character where it is related to the extrusion conditions and depending on the ingredients in blends. It showed a contrary trend as compared to ER for the same extrudates. The data presented in Table (9) showed that, The BD increased by adding Nile perch fish flour. These results were agreed with the results which obtained by Gujska and Kahan (1990); Saleh (1996); Abd El-Hady and Habiba (1996) and Abd El-Hady et al. (1997).

\section{3- Water Absorption Index (WAl):}

In general, adding protein flours individually or in mixture to rice grits caused a reduction in WAl values. Here, it is interesting to note that presence of more hydrophilic sites exposed in matrix allowing more water to immigrate in (Bhattacharya et al., 1986). These sites depend on protein contents and the species of amino acids, which vary form kind to another in and so on the undesirable effect of extrusion temperature.

\section{4- Water Solubility Index (WSI):}

The data presented in Table (9) indicated that, addition of fish flour to rice grits increase the WSI in most of samples. The highest value $(0.45 \%)$ was obtained in extrudates which contained $12.5 \%$ fish flour, while the lowest 
value $(0.43 \%)$ was obtained in extrudates which contained a mixture of fish flours at levels of $10 \%$. These results probably because the soluble materials which had formed during extrusion cooking (degraded starchy and protein material) could, in some cases, bind to form insoluble complexes. The same results were obtained by Abd El-Hady et al. (1997).

\section{5- Breaking Strength (BS):}

Data presented in Table (9) showed the effect of substitution of rice grits with fish flour on the breaking strength of the resultant extrudates. In general, adding fish flour individually to rice grits caused a slight increase in

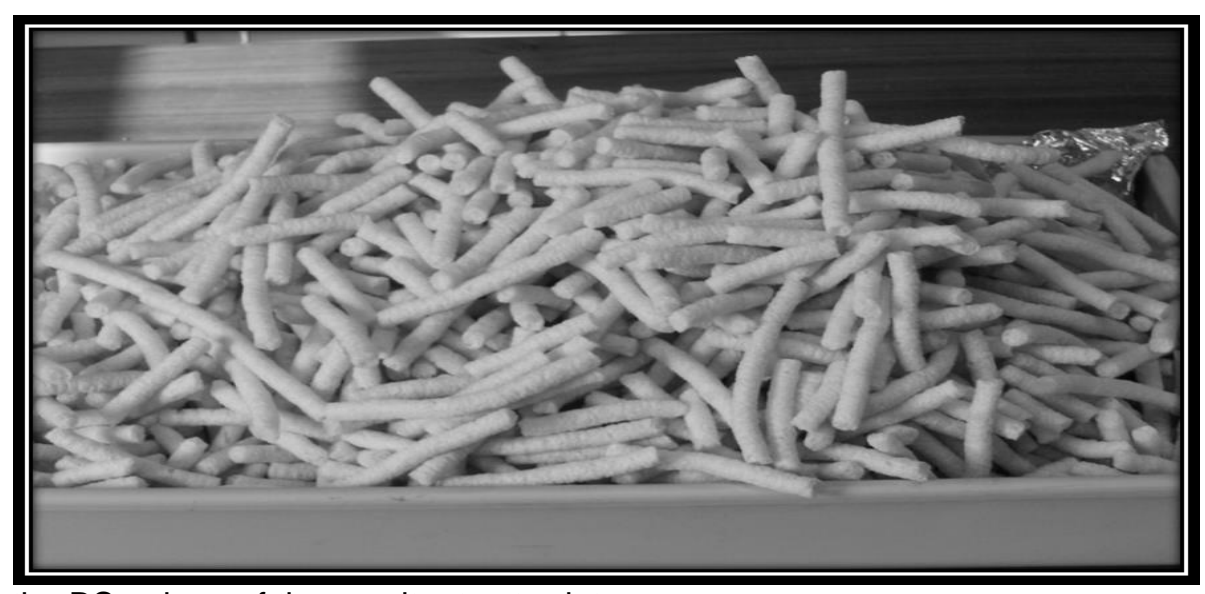

the BS-values of the resultant extrudates.

Fig (2): The extruded final snack product contains $10 \%$ Nile perch flour fish.

\section{Sensory evaluation:}

Sensory evaluation scores of fortified rice snack with fish flour are shown in Table (10).

Fig(2) Showed the picture of extruded final product contains $10 \%$ Nile perch flour fish.

Table (10): Effect of adding Nile perch fish flour on the sensory properties of rice flour extrudate.

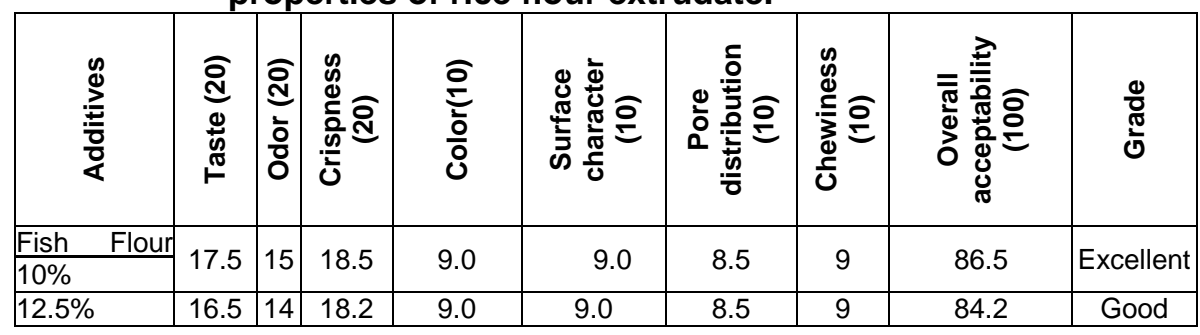


Atwa, Manal A. et al.

Data indicated that the scores were high in both samples in spit of odor (flavor) scores of the prepared sample which gained moderate score.

It is clear from the previous results that Taste was gained a good score in both products, no strong odor (flavors) were detected in both samples by increasing fish flour content in blends. This is because the volatiles were lost during extrusion.Same result was obtained by Almeida Domingues et al. (1990). Crispness gained high score (18.2-18.2) in both samples. This result was related to the ER and $B D$ value, which significantly affected on the denseness of extrudates. Skierkowski et al. (1990) reported that crispness score were highest in blends containing $13-16 \%$ protein content. At values below and above this range, scores decreased indicated that the extrudates would not be acceptable to consumers. Also, it was noticed during sensory evaluation that, the extrudate color became more brown by increasing fish flour in blends. These results may be due to the chemical reactions such as caramelization of carbohydrates; Maillard reaction and effects of lipids and protein. The same trends were noticed by many authors (Almieda Domingues et al.., 1990; Gujska and Khan, 1990 and 1991; Singh et al., 1996; Abd ElHady and Habiba, 1996 and Abd El-Hady et al. 1997. Also, it appeared that, increasing fish flour contents in blends gained a good score for surface characteristics of extrudates. This is due to the relationship between temperature, moisture, protein content of extrudates and the surface texture of products (smooth and fragile). Regarding to chewiness character, it could note a defference in both samples. These results probably because increasing protein percentage in extrudates in high temperature led to hardness and toughness in texture.

Finally, the overall acceptability scores indicated that, it could be obtained on fortified extrudates with fish flour at excellent or good grade by using Nile perch fish flour at levels 10 and $12.5 \%$.

Number of studies have reported successful incorporation of fish flesh or fish powder into starch-based materials by extrusion processes to produce nutritious extruded products that were acceptable by consumers (Suknark et al.1998 and 1999)

In conclusion, results of this study indicated that extrusion of Nile perch fish with rice grits could produce directly expanded snake foods that would be more nutritious than the other commercial snacks in taste and overall acceptability.

\section{REFERENCES}

A. O. A. C. (2008). Analytical Chemists Association of Official Analytical Chemists, Inc, Arlington west of Virginia, USA.

Abd El-Hady, E. A. and Habiba R. A. (1996). Effect of ingredients on properties of wheat flour-based extruded loops. Food for special Dietary use, Conference and Exhibition Suez Canal University, 11-12 March, Imsailia, Egypt. 
Abd El-Hady, E. A.; Mostafa, G. A. and El-Samahy, S. K. (1997). Production of rice extruadates with high nutritional value. Egyptian Journal of Applied Science, Vol. 12 No. 12 pp. 172-186.

ABd EL -Hady,E.A, el- samahy,s.k, mostafa, g.a. and youssef,k.m.(2002). Use of date pulp and concentrate in rice - based extrudates. Getreide mehl und Brot,56(3):179-185.

Abu-Foul, N. S. L. (1990). Physico-chemical, nutritional and technological studies on food uses of glanded and glandless cottonseed protein. Ph. D. Thesis, Fac. Agric. Alex. Univ. Alexandria, Egypt.

Almeida-Domingues, N. G; Valencia, M.E. and Higuera-Ciapara, I. (1990). Formulation of corn-based snacks with high nutritive value: biological and sensory evaluation. J. Food Sci., 55 (1): 228-231.

Andersson, R. A.; Conway, H. F; Pfeifer, V.F. and Griffin, JR.E.L. (1969). Gelatinization of corn grits by roll-extrusion-cooking. Cereal Sci. Today, 14: 4 .

Augustin M. A. and Sanguansri, L. (2003). Polyunsaturated fatty acid: Delivery, innovation and incorporation into foods .Food Australia, 55: 294-296.

Benson., J. V. and Patterson, J. A. (1965). Accelerated automatic chromatographic analysis of amino acids on a spherical resin. Anal chem. 37 (9) :1108-1110.

Bhattacharya, M.; Hanna, M.A. and Kaufman, R.E. (1986). Textural properties of extruded plant protein blends. J. Food Sci., 51 (4): 988993.

Boonyasirikul, P. (1998). Production of Snacks at The Institute of Food Research and Product Development. Kasetsart Univeristy, Bangkok, pp. 47-52.

Chinnaswamy, R. and Hanna, M. A. (1998). Expansion, color and shear strength properties of corn starches extrusion-cooking with urea and salt. Starch/ Staerke, 40: 186-190.

Choudhury, G.S. and Gogoi, B.K. (1995). Extrusion processing of fish muscle: a review. J. Aq. Food Prod. Technol. 4(4): 37-67.

Clayton, J. T. and Miscourides, D. N. (1992). Extruder texturized foods from underutilized fish tissue. J. Aq. Food Prod. Technol., 1(3/4), 65-89.

Egyptian Standards Spesifications ,2005.Processed Cereal- Based foods for infants and children. ES:3284/2005.

Dziezak, J. d. (1991). Romancing the kernel: A salute to rice varieties. Food Technol., 45(6): 74-80.

Faubion; J.M; Hoseney, R. C. and Seirb, P. A. (1982). Functional of grain components in extrusion. Cereal Food World, 27: 212.

Geoffery R.N, and D.L. streines. 2003 .statistics, third edition, B.C Decker Inc, Hamilton - London. Iler R.K., The chemistry of silica (wiley, New York, 1979).

Gouda,h.2002. microbiological studies on some fish aquacultures in Egypt, B.SC. thesis Faculty of Agriculture-Cairo university -pp52-69. 
Grantham, g. J. (1981). Minced fish technology: a review. FAO Fisheries technical Paper, 216: 1-72.

Gujska, E. and Khan k. (1990). Effect of temperature on protperties of extrudates from high starch fractions of Navy, Pinto and Garbanzo. J. Food Sci., 55 (2): 466-469.

Gujska, E. and Khan, K. (1991). Functional properties of extrudates from high starch fractions of navy and pinto beans and corn meal blend with legume high protein fractions. J. Food Sci., 56 (2): 431-435.

ISO, International standards organizations(2002). Microbiology of food and animal feeding stuffs- Horizontal methods for the detection of total plate count,coliforms and faecal coliforms.

Kris-Etherton, P. M. Taylor D. S., Yu-Poth, S., Huth, P., Moriarty, K., Fishell, v. et al.. (2000). Polyunsaturated fatty acids in the food chain in the United States. American Journal of Clinical Nutrition. 71 (Suppl.), 179s$188 \mathrm{~s}$.

Matz, S. A. (1976). Snack Food technology, AVI Publishing Co., Westport. CT.

Murray, B. P. and Stanley, D. W. (1989'). Improved utilization of fish proteincoextrusion of mechanically deboned salted minced fish. Can. Inst. Food Sci. Technol., 13(3): 125-134.

NAS (National Academy of Science ,2001). Dietary Reference Intakes for Vitamin A, Vitamin K, Arsenic, Boron, Chromium, Copper, lodine, Iron, Manganese, Molybdenum, Nickel, Silicon, Vanadium, and Zinc. National Academies of science ,Press, Washington, DC, http://www.nap.edu

Okezie . B.O, and Bello.A.B (1988). Physicochemical and Functional properties of winged bean flour and isolate compared with soy isolate .J.Food sci.,53;450-454.

Oxoid, Manual (2000). The Oxoid manual of culture media ingredients and other laboratory services. $8^{\text {th }}$ edition. Oxiod, Ltd.

Pringle, R. M. (2005). The origins of the Nile perch in lake Victoria. Bioscience, 55: 780-787.

USDA,(2002) . United States Department of Agriculture (USDA), Food Safety Inspection Service. 2002. Isolation and identification of Salmonellafrom meat, poultry and egg products, USDA/FSIS Microbiology Laboratory Guidebook, $3^{\text {rd }}$ ed. U.S. Department of Agriculture, Food Safety Inspection Service, Washington, D.C

Rhee . K . S, E . S . Kim, BM . JunG and K . C . Rhee (2004) .Extrusion of minced catfish with corn and defatted soy flours for snack foods. J .Food Processing, $28: 288-301$.

Saleh, H. S. (1996). Production and evaluation of extrudates from yellow corn grits blends. M. Sc. Thesis Fac. of Agric. Cairo Univ., Cairo, Egypt.

Simpopoulos, A. P. (2000). Symposium: role of poultry products in enriching the human diet with n-3 PUFA, human requirement for $n-3$ polyunsaturated fatty acids. Poultry Science, 79: 961-970.

Singh, R. K; Nielson, S.S.; Chambers j. V., Martines-Serna M. and Villota, R. (1996). Selected characteristics of extruded blends of milk protein 
raffinate on nonfat dry milk with corn flour. J. Food Processing and Preservation (USA), 15(4): 285-302.

Skierkowski, K.; Gujska, E. and Khan, K. (1990). Instrumental and sensory evaluation of textural properties of extrudates from blends of high starch/ high protein fractions of dry beans. J. Food Sci., 55 (4): 10811087.

Smith DP, Berrang ME, Feldner PW, Phillips RW, and Meinersmann RJ. 2004. Detection of Bacillus cereus on selected chicken products .J .Food Prot. Aug;67(8):1770-3.

Suknark, K., McWatters, K. H. \& Phillips, R.D. (1998). Acceptability by American and Asian extruded fish and peanut snack products. J. Food Science, 63: 721-725.

Suknark, K., Phillips, R. D. and Huang. Y. W. (1999). Tapioca-fish and tapioca0peanut snacks by twin-screw extrusion and deep-fat frying. J. Food Science, 64, 303-308.

Yu, S. Y. Mitchell, J. R. and Abdullah, A. (1981). Production and acceptability testing of fish crackers (keropok) prepared by extrusion method. J. Food Technol., 16: 51-58.

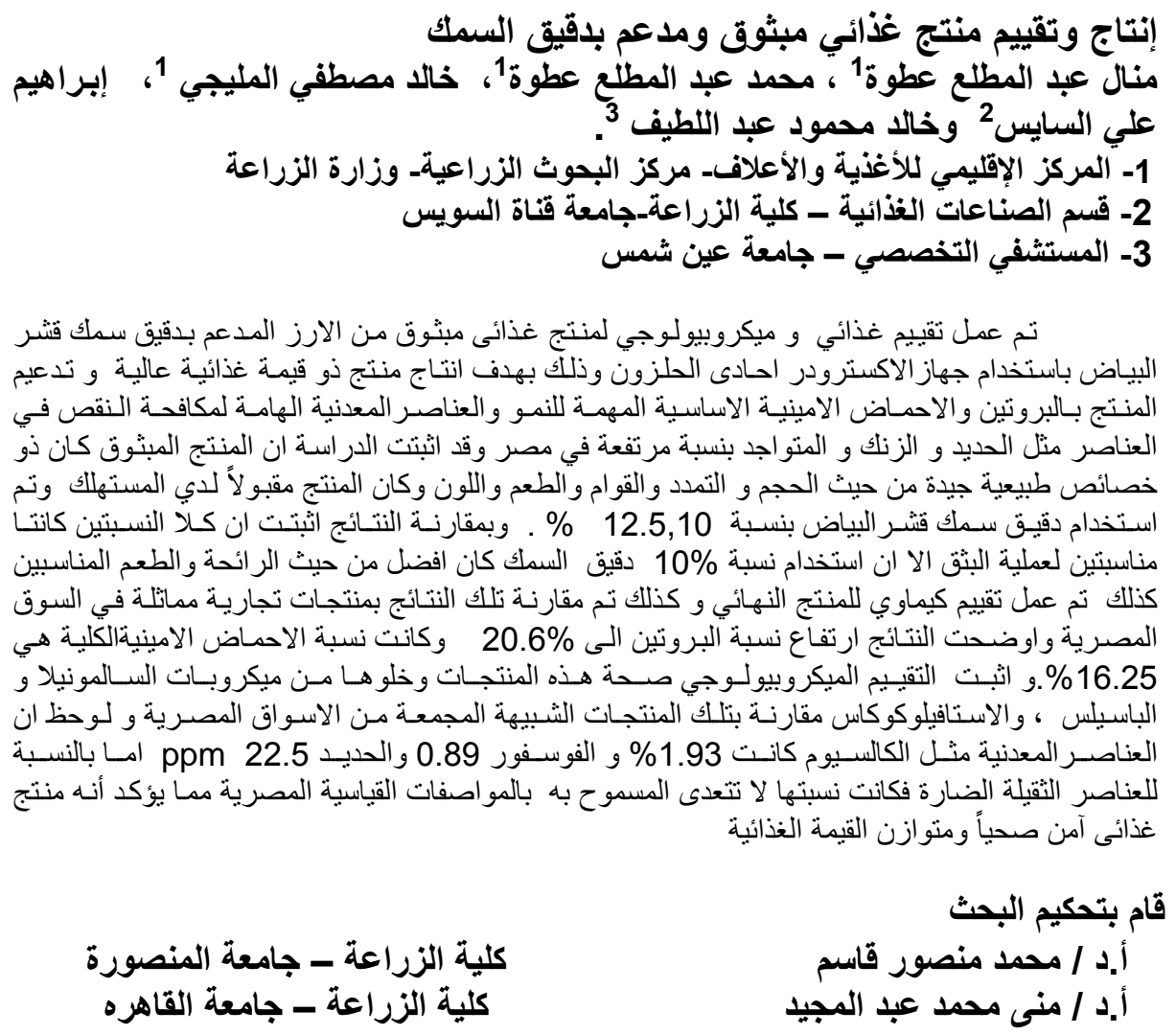


Atwa, Manal A. et al. 
J.Agric.Chem.and Biotechn., Mansoura Univ.Vol. 4 (4), April, 2013 

J.Agric.Chem.and Biotechn., Mansoura Univ.Vol. 4 (4): 155 - 169, 2013

Table (3):The mean and standard deviation values of Amino acids for the ten fish flour varieties.

\begin{tabular}{|c|c|c|c|c|c|c|c|c|c|c|c|}
\hline \multirow{2}{*}{$\begin{array}{l}\text { Amino acids } \\
\text { g/100g dry } \\
\text { sample }\end{array}$} & \multicolumn{10}{|c|}{ Fish flour varieties } & \multirow[b]{2}{*}{$\begin{array}{c}\text { LSD } \\
\mathrm{P}<0.05\end{array}$} \\
\hline & Red mullet & Mullet & Sardines & $\begin{array}{c}\text { Nile } \\
\text { perch }\end{array}$ & Tilapia & $\begin{array}{c}\text { Synodontid } \\
\text { a }\end{array}$ & Salmon & Mackerel & Tuna & $\begin{array}{c}\text { Grass } \\
\text { carp }\end{array}$ & \\
\hline Aspartic & \begin{tabular}{|c|}
$\mathrm{F}$ \\
7.38 \\
\pm 2.6 \\
\end{tabular} & $\begin{array}{l}\mathrm{D} \\
8.31 \\
\pm 3.3 \\
\end{array}$ & $\begin{array}{c}\mathrm{F} \\
7.27 \\
\pm 3.1 \\
\end{array}$ & $\begin{array}{c}A \\
10.73 \\
\pm 4.1 \\
\end{array}$ & $\begin{array}{r}\mathrm{B} \\
9.39 \\
\pm 4.4 \\
\end{array}$ & \begin{tabular}{c|}
$\mathrm{C}$ \\
8.90 \\
\pm 4.7 \\
\end{tabular} & $\begin{array}{c}\mathrm{H} \\
5.18 \\
\pm 3.3 \\
\end{array}$ & $\begin{array}{c}G \\
6.90 \\
\pm 3.6 \\
\end{array}$ & $\begin{array}{l}\mathrm{C} \\
9.05 \\
\pm 4.6 \\
\end{array}$ & $\begin{array}{c}\mathrm{E} \\
7.66 \\
\pm 5\end{array}$ & 0.170 \\
\hline Therionin & $\begin{array}{l}3.16 \\
\pm 2.1 \\
\end{array}$ & $\begin{array}{l}A \\
4.88 \\
\pm 1.7 \\
\end{array}$ & $\begin{array}{r} \\
3.10 \\
\pm 1.8 \\
\end{array}$ & $\begin{array}{r}\mathrm{B} \\
4.35 \\
\pm 2.2 \\
\end{array}$ & $\begin{array}{l}\mathrm{C} \\
3.94 \\
\pm 3\end{array}$ & $\begin{array}{r}0 \\
3.76 \\
\pm 2.6 \\
\end{array}$ & $\begin{array}{l}G \\
G .26 \\
\pm 2.7 \\
\end{array}$ & $\begin{array}{r}F \\
3.05 \\
\pm 2.2 \\
\end{array}$ & $\begin{array}{l}0 \\
3.74 \\
\pm 2 \\
\end{array}$ & $\begin{aligned} & E \\
& 3.53 \\
& \pm 3.2 \\
&\end{aligned}$ & 0.170 \\
\hline Serine & $\begin{array}{l}\quad D \\
2.52 \\
\pm 3.2\end{array}$ & $\begin{array}{l}\mathrm{C} \\
2.88 \\
\pm 3\end{array}$ & $\begin{array}{l}1.52 \\
\pm 3.9\end{array}$ & $\begin{array}{l}\text { A } \\
3.55 \\
\pm 2.5\end{array}$ & $\begin{array}{l}3.27 \\
\pm 2.7\end{array}$ & $\begin{array}{l}2.91 \\
\pm 3.1\end{array}$ & $\begin{array}{l}1.65 \\
\pm 2.8\end{array}$ & $\begin{array}{l}D \\
2.52 \\
\pm 2.6 \\
\end{array}$ & $\begin{array}{l}3.16 \\
\pm 2.2 \\
\end{array}$ & $\begin{array}{l}\mathrm{D} \\
2.65 \\
\pm 3.5 \\
\end{array}$ & 0.164 \\
\hline Glutamic & $\begin{array}{c}G \\
12.23 \\
\pm 4.5\end{array}$ & $\begin{array}{c}\mathrm{D} \\
13.65 \\
\pm 4.4\end{array}$ & $\stackrel{H}{H}$ & $\begin{array}{c}E \\
13.17 \\
\pm 2.9\end{array}$ & $\begin{array}{c}A \\
15.85 \\
\pm 3.6\end{array}$ & $\begin{array}{c}C \\
14.85 \\
\pm 5\end{array}$ & $\begin{array}{l}.06 \\
\pm 3.8\end{array}$ & $\begin{array}{r}11.38 \\
\pm 4.5 \\
\end{array}$ & $\begin{array}{c}\mathrm{B} \\
15.17 \\
\pm 4.1\end{array}$ & $\begin{array}{r}F \\
12.4 \\
\pm 4.7\end{array}$ & 0.170 \\
\hline Proline & $\begin{array}{l}.6 \\
2.68 \\
\pm 6.1\end{array}$ & $\begin{array}{c}-4.4 \\
\text { A } \\
8.68 \\
\pm 6.8 \\
\end{array}$ & $\begin{array}{c}F \\
2.36 \\
\pm 6.3 \\
\end{array}$ & $\begin{array}{l}\mathrm{C} \\
3.12 \\
\pm 5.8 \\
\end{array}$ & $\begin{array}{r}3.3 \\
3.32 \\
\pm 7.1 \\
\end{array}$ & $\begin{array}{l}\mathrm{E} \\
2.62 \\
\pm 7.4 \\
\end{array}$ & $\begin{array}{l}\mathrm{H} \\
1.51 \\
\pm 6.4 \\
\end{array}$ & $\begin{array}{r}G \\
1.97 \\
\pm 5.9 \\
\end{array}$ & $\begin{aligned} & \mathrm{D} \\
& 2.82 \\
& \pm 6.3 \\
&\end{aligned}$ & $\begin{array}{l}E F \\
2.43 \\
\pm 6 \\
\end{array}$ & 0.181 \\
\hline Glycine & $\begin{array}{l}E F \\
3.44 \\
\pm 4.4\end{array}$ & $\begin{array}{l}\mathrm{D} \\
3.74 \\
\pm 4.5\end{array}$ & $\begin{array}{l}3.58 \\
\pm 2.6\end{array}$ & $\begin{array}{l}C \\
4.02 \\
\pm 3.7\end{array}$ & $\begin{array}{l}\text { A } \\
5.21 \\
\pm 3.5\end{array}$ & $\begin{array}{l}C \\
3.97 \\
\pm 4.4\end{array}$ & $\begin{array}{l}\mathrm{H} \\
2.26 \\
\pm 3.5\end{array}$ & $\begin{array}{l}G \\
.96 \\
\pm 4.9\end{array}$ & $\begin{array}{l}\mathrm{B} \\
4.36 \\
\pm 2.7\end{array}$ & $\begin{array}{l}3.37 \\
\pm 4.9 \\
\end{array}$ & 0.170 \\
\hline Alanine & $\begin{array}{l}\mathrm{D} \\
4.05 \\
\pm 2.9\end{array}$ & $\begin{array}{l}\mathrm{D} \\
4.15 \\
\pm 2.1\end{array}$ & $\begin{array}{l}\quad \mathrm{E} \\
3.81 \\
\pm 3.5\end{array}$ & $\begin{array}{l}A \\
5.15 \\
\pm 2.8\end{array}$ & $\begin{array}{l}A \\
5.17 \\
\pm 3.6\end{array}$ & $\begin{array}{l}C \\
4.38 \\
\pm 4.1\end{array}$ & $\begin{array}{l}G .6 \\
2.71 \\
\pm 3.2\end{array}$ & $\begin{array}{l}\mathrm{F} \\
3.53 \\
\pm 4.7\end{array}$ & $\begin{array}{l}\quad \mathrm{B} \\
4.54 \\
\pm 3.8\end{array}$ & $\begin{array}{r}\mathrm{D} \\
4.11 \\
\pm 3.5\end{array}$ & 0.170 \\
\hline Cystine & $\begin{array}{l}\mathrm{BC} \\
1.08 \\
\pm 2.6 \\
\end{array}$ & $\begin{array}{r}A B \\
1.13 \\
\pm 2.9 \\
\end{array}$ & $\begin{array}{l}\mathrm{CD} \\
0.94 \\
\pm 3\end{array}$ & $\begin{array}{r}A \\
1.23 \\
\pm 2.7 \\
\end{array}$ & $\begin{array}{r}\mathrm{AB} \\
1.16 \\
\pm 2.2 \\
\end{array}$ & $\begin{array}{l}\mathrm{AB} \\
1.12 \\
\pm 3.6 \\
\end{array}$ & $\begin{array}{l}\mathrm{CD} \\
0.98 \\
\pm 2.8 \\
\end{array}$ & $\begin{array}{l}\mathrm{CD} \\
0.91 \\
\pm 2.6 \\
\end{array}$ & $\begin{array}{l}\mathrm{AB} \\
1.12 \\
\pm 4.5 \\
\end{array}$ & $\begin{array}{l}\mathrm{D} \\
0.89 \\
\pm 5.8 \\
\end{array}$ & 0.170 \\
\hline Valine & $\begin{array}{l}C .30 \\
3.30 \\
\pm 3.2\end{array}$ & $\begin{array}{l}C \\
3.46 \\
\pm 3\end{array}$ & $\begin{array}{c}\mathrm{D} \\
3.14 \\
\pm 1.8\end{array}$ & $\begin{array}{c}A \\
4.44 \\
\pm 3.7\end{array}$ & $\begin{array}{r}B \\
3.76 \\
+2.8\end{array}$ & $\begin{array}{r}B \\
3.76 \\
+2.6\end{array}$ & $\begin{array}{c}\mathrm{F} \\
2.25 \\
\pm 4.2\end{array}$ & $\begin{array}{r}\mathrm{E} \\
2.92 \\
\pm 2.8\end{array}$ & $\begin{array}{c}C \\
3.37 \\
\pm 3\end{array}$ & $\begin{array}{r}\mathrm{D} \\
3.15 \\
\pm 4.5\end{array}$ & 0.170 \\
\hline Methionin & $\begin{array}{l}\mathrm{BC} \\
2.45 \\
\pm 4.8 \\
\end{array}$ & $\begin{array}{c}\mathrm{B} \\
2.53 \\
\pm 4.2 \\
\end{array}$ & $\begin{array}{r}\text { CD } \\
2.35 \\
\pm 4.6 \\
\end{array}$ & $\begin{array}{l}\text { CD } \\
2.34 \\
\pm 5.1 \\
\end{array}$ & $\begin{array}{r}A \\
2.70 \\
\pm 3.8 \\
\end{array}$ & $\begin{array}{r}\text { A } \\
2.76 \\
\pm 4.8\end{array}$ & $\begin{array}{l}\mathrm{E} \\
0.16 \\
\pm 3.7 \\
\end{array}$ & $\begin{array}{r}\mathrm{D} \\
2.20 \\
\pm 2.9 \\
\end{array}$ & $\begin{array}{c}\overline{B C} \\
2.48 \\
\pm 3\end{array}$ & $\begin{array}{r}\mathrm{CD} \\
2.39 \\
\pm 2.6 \\
\end{array}$ & 0.163 \\
\hline Isoleucine & $\begin{array}{r}\mathrm{D} \\
3.23 \\
+3.4 \\
\end{array}$ & $\begin{array}{c}C \\
3.54 \\
\pm 3 \\
\end{array}$ & $\begin{array}{r}\mathrm{DE} \\
3.15 \\
\pm 2.9 \\
\end{array}$ & $\begin{array}{c}\mathrm{A} \\
4.54 \\
\pm 4.5 \\
\end{array}$ & $\begin{array}{r}\mathrm{B} \\
3.75 \\
\pm 3.9 \\
\end{array}$ & $\begin{array}{c}C \\
3.57 \\
\pm 3.6 \\
\end{array}$ & $\begin{array}{r}G \\
2.10 \\
\pm 3.5 \\
\end{array}$ & $\begin{array}{r}5 \\
2.73 \\
+2.9 \\
\end{array}$ & $\begin{array}{r}0 \\
3.22 \\
+2.7 \\
\end{array}$ & $\begin{array}{r}E \\
3.0 \\
\pm 2.6 \\
\end{array}$ & 0.170 \\
\hline Leucine & $\begin{array}{l}\text { DE } \\
5.86 \\
\pm 2.7\end{array}$ & $\begin{array}{c}C \\
6.46 \\
\pm 3.1\end{array}$ & $\begin{array}{r}5.70 \\
\pm 3.4\end{array}$ & $\begin{array}{c}\text { A } \\
8.30 \\
\pm 4.5\end{array}$ & $\begin{array}{c}\mathrm{B} \\
6.91 \\
\pm 2\end{array}$ & $\begin{array}{c}C \\
6.57 \\
\pm 3.9\end{array}$ & $\begin{array}{r}\mathrm{H} \\
3.68 \\
\pm 3.3\end{array}$ & $\begin{array}{c}\mathrm{G} \\
4.92 \\
\pm 3.2\end{array}$ & $\begin{array}{c}\mathrm{D} \\
5.90 \\
\pm 3.9\end{array}$ & $\begin{array}{c}5.31 \\
\pm 2\end{array}$ & 0.170 \\
\hline Phenylalanine & $\begin{array}{r}C \\
3.02 \\
\pm 3.8 \\
\end{array}$ & $\begin{array}{l}C \\
3.04 \\
+5.6 \\
\end{array}$ & $\begin{array}{c}C \\
3.02 \\
+4.6 \\
\end{array}$ & $\begin{array}{c}A \\
4.02 \\
\pm 4.5 \\
\end{array}$ & $\begin{array}{r}3 \\
3.47 \\
\pm 3.9 \\
\end{array}$ & $\begin{array}{r}\mathrm{B} \\
3.47 \\
+2.7 \\
\end{array}$ & $\begin{array}{r}E \\
2.04 \\
\pm 3.6 \\
\end{array}$ & $\begin{array}{r}\mathrm{D} \\
2.53 \\
\pm 5.2 \\
\end{array}$ & $\begin{array}{c}C \\
3.10 \\
+4.7 \\
\end{array}$ & $\begin{array}{r}\mathrm{D} \\
2.62 \\
\pm 3.7 \\
\end{array}$ & 0.170 \\
\hline Histidine & $\begin{array}{c}C \\
2.51 \\
\pm 1.2 \\
\end{array}$ & $\begin{array}{r}C \\
2.48 \\
\pm 2.6 \\
\end{array}$ & $\begin{array}{r}\text { B } \\
3.47 \\
+1.3 \\
\end{array}$ & $\begin{array}{r}.2 .41 \\
\pm 1.6 \\
\end{array}$ & $\begin{array}{r}C \\
2.47 \\
\pm 1.5 \\
\end{array}$ & $\begin{array}{r}D E \\
2.16 \\
\pm 2.1 \\
\end{array}$ & $\begin{array}{r}E \\
2.0 \\
\pm 2.6 \\
\end{array}$ & $\begin{array}{r}C \\
2.40 \\
\pm 2 \\
\end{array}$ & $\begin{array}{r}\mathrm{D} \\
2.20 \\
+1.2 \\
\end{array}$ & $\begin{array}{r}A \\
3.74 \\
+1.4 \\
\end{array}$ & 0.170 \\
\hline Lysine & $\begin{array}{r}\mathrm{D} \\
6.45 \\
+2.3 \\
\end{array}$ & $\begin{array}{r}C \\
6.78 \\
\pm 2.5 \\
\end{array}$ & $\begin{array}{r}6.03 \\
\pm 3.9 \\
\end{array}$ & $\begin{array}{r}A \\
9.13 \\
\pm 4.6 \\
\end{array}$ & $\begin{array}{r}\mathrm{B} \\
7.24 \\
+2.1 \\
\end{array}$ & $\begin{array}{r}C \\
6.70 \\
+3.2 \\
\end{array}$ & $\begin{array}{r}4 \\
3.78 \\
+1.6 \\
\end{array}$ & $\begin{array}{r}G \\
4.97 \\
\pm 1.9 \\
\end{array}$ & $\begin{array}{l}6.24 \\
6.24 \\
+3.2 \\
\end{array}$ & $\begin{array}{r}G \\
5.06 \\
+3.3 \\
\end{array}$ & 0.170 \\
\hline Argnine & $\begin{array}{l}\mathrm{DE} \\
3.64 \\
+12\end{array}$ & $\begin{array}{l}\text { B } \\
3.93 \\
+13\end{array}$ & $\begin{array}{c}A \\
4.17 \\
+22\end{array}$ & $\begin{array}{l}\mathrm{CD} \\
3.70 \\
+2\end{array}$ & $\begin{array}{l}C D \\
3.70 \\
+3\end{array}$ & $\begin{array}{l}F G \\
3.37 \\
+4.1\end{array}$ & $\begin{array}{r}4.66 \\
2.66\end{array}$ & $\begin{array}{c}G \\
3.31 \\
+26\end{array}$ & $\begin{array}{l}\mathrm{BC} \\
3.8 \\
+3.1\end{array}$ & $\begin{array}{l}\mathrm{EF} \\
3.50 \\
+36\end{array}$ & 0.181 \\
\hline
\end{tabular}

$A, B, C, D, E, F, G, H, I$ and $J$. (comparison between amino acids of fish varieties) Means in the same row with different letters are significantly different at $p \leq 0.05$. 